\title{
Seed remains of common millet from the 4th (Mongolia) and 15th (Hungary) centuries: AFLP, SSR and mtDNA sequence recoveries
}

\author{
G. Gyulai ${ }^{1,2 *}$, M. Humphreys ${ }^{2}$, R. Lagler ${ }^{1}$, Z. Szabo ${ }^{1}$, Z. Toth ${ }^{1}$, A. Bittsanszky ${ }^{1}$, F. Gyulai ${ }^{3}$ \\ and L. Heszky ${ }^{1}$
}

${ }^{1}$ St. Stephanus University Genetics and Pland Breeding and the Hungarian Academy of Sciences-St. Stephanus University Research Group for Molecular Plant Breeding, Godollo, H-2103, Hungary; ${ }^{2}$ Institute of Grassland and Environmental Research, Plas Gogerddan, Aberystwyth, SY23 3EB, UK; ${ }^{3}$ Institute of Agrobotany, Tapioszele, $\mathrm{H}-2766$, Hungary

\begin{abstract}
Seed remains of common millet (Panicum miliaceum L.) were excavated from sites of $A D$ 4th-century Darhan (Mongolia), and AD 15th-century Budapest (Hungary). Because the 15th-century medieval grains looked so intact, a germination test was carried out under aseptic conditions, which resulted in swelling of the grains but no cell proliferation or germination. Ancient DNA (aDNA) was extracted from the aseptic grains; analysed for amplified fragment length polymorphisms (AFLP), simple sequence repeats (SSR) and mitochondrial DNA (mtDNA); and compared with the modern millet cultivar 'Topaz'. AFLP analysis revealed that extensive DNA degradation had occurred in the 4th-century ancient millet, resulting in only 2 (1.2\%) AFLP fragments (98.8\% degradation) amplified by MseCAA-EcoAGT, compared to the 15th-century medieval millet, with 158 (40\%) fragments (60\% degradation), and modern millet cultivar 'Topaz' with 264 fragments (100\%). EcoAGT-MseCAA was found to be the most effective selectiveprimer combination for the analysis of medieval and modern millet. Eight AFLP fragments were sequenced after re-amplification and cloning. Microsatellite (SSR) analysis at the nuclear gln4, sh1, rps28 and rps15 loci revealed one SNP (single nucleotide polymorphism) at the 29th position ( $A \rightarrow G$ ) of rps28 locus, compared to modern millet. An mtDNA fragment (Mbol), amplified at the 18S-5S ribosomal DNA (rDNA) locus in the medieval millet, showed no molecular changes compared to modern millet. The results underline the significance of aDNA extraction and analysis of
\end{abstract}

*Correspondence

Email: gyulai.gabor@mkk.szie.hu excavated seeds for comparative analysis and molecular reconstruction of ancient and extinct plant genotypes.

Keywords: ancient DNA, excavated seeds, Panicum miliaceum

\section{Introduction}

Common millet (Panicum miliaceum, $2 n=4 x=36$ ) is one of the most ancient grain crops, with the oldest historical reports from 5000-3200 BC (Ho, 1977). However, various plant remains from c. 12,000$8000 \mathrm{BP}$ have been recovered from the Hoabinhian culture (Gorman, 1969; Walters, 1989). Panicum became a typical food of Sumer and northern India, together with barley (Hordeum vulgare), in about 2500 $\mathrm{BC}$. For the nations of steppic Scythia, such as the Celts or Hungarians in $2000 \mathrm{BC}$, common millet was the first crop to produce two harvests in 1 year. In the ancient Chinese 'Book of Poetry' (Shih Ching), written about 1000-500 BC, nine poems mention common millet (Keng, 1974). This crop spread from the Steppes through Europe via tribes of the Celts, Huns, Avars and Hungarians, and also through the region of the 'Fertile Crescent' and Africa (Harlan, 1971). It was the milium (millet) of Romans (Smith, 1976). Millet was introduced to North America in the 17th century (Colosi and Schaal, 1997). New cultivars were registered recently.

Ancient DNA (aDNA) samples, recovered from excavated remains of plants and animals, supply unique materials not only for the analysis of postmortem DNA degradation (Threadgold and Brown, 2003), but also for tracing crop domestication and microevolution (Brown, 1999), with a final aim for 
complete genome reconstruction of extinct organisms (Cooper et al., 2001; Pääbo et al., 2004) and genotypes (Szabo et al., 2005). In this study, we present the aDNA analyses of 1600-year-old common millet excavated in Mongolia, and 600-year-old millet from a 15th-century site in Hungary, together with a comparison with the modern cultivar 'Topaz' as a control. Amplified fragment length polymorphism (AFLP) analysis was used to amplify aDNA fragments in high numbers and to estimate the degradation of aDNA. Locusspecific microsatellites (simple sequence repeats, SSR) were used to show authenticity of the Panicum analysed, and to amplify aDNA at the nuclear gene loci of $g \ln 4, s h 1, r p s 28$ and rps15. High copy number ancient mitochondrial DNA at the 18S-5S ribosomal DNA (rDNA) locus (Mbo I) was also recovered and analysed.

\section{Materials and methods}

\section{Seed samples}

Seed remains of common millet (P. miliaceum) from the 4th-century site (third grave, Darhan, Mongolia, excavated in 1969) (50 seeds) and 15th-century sites (150 seeds) (eighth well, Mansion Teleki, King's Palace, Budapest, Hungary) (Nyekhelyi, 2003) were used in this study. Wet-sieved sediment samples were processed by floatation, followed by seed sorting and identification in the laboratory (see Fig. 1). For comparative analyses the modern common millet cultivar 'Topaz' (ABI, Tapioszele, Hungary) was included.

The excavated seeds at the Budapest site (see Table 2) were examined under a light microscope (Wild M32, Leica, Hungary) and identified to species based upon seed morphology, using the Schermann Manual (1966). Seeds were also compared to the samples of a seed bank of the Middle European Seed and Fruit Collections (Gyulai, 2000).

\section{Aseptic culture}

Seed remains were washed with detergent $(3 \mathrm{~min})$ and rinsed three times with distilled water ( $3 \mathrm{~min})$, followed by surface sterilization with ethanol $(70 \%$ $\mathrm{v} / \mathrm{v})$ for $1 \mathrm{~min}$ and a commercial bleaching agent $(8 \%$ $\mathrm{NaOCl} \mathrm{w/v)} \mathrm{for} 1 \mathrm{~min}$; followed by three rinses with sterile distilled water, according to general tissue culture technique, and incubated for 3 months in aseptic tissue culture medium F6 (see Fig. 2; Gyulai et al., 2003) to eliminate contamination before DNA extraction. Grains of the modern variety were also surface sterilized. Exogenously and endogenously

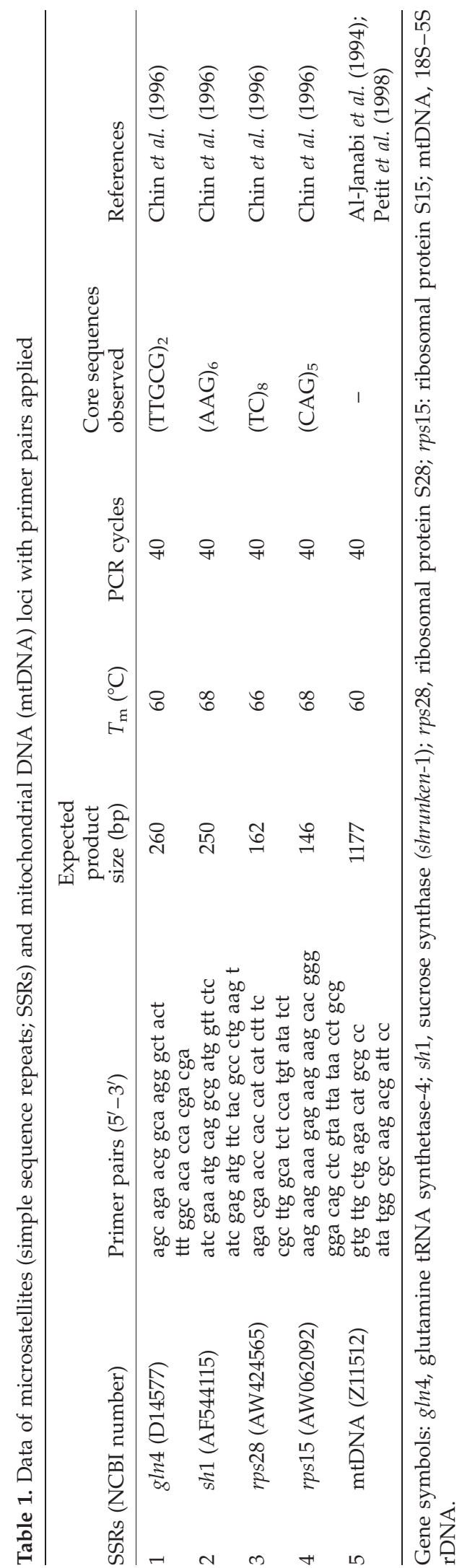




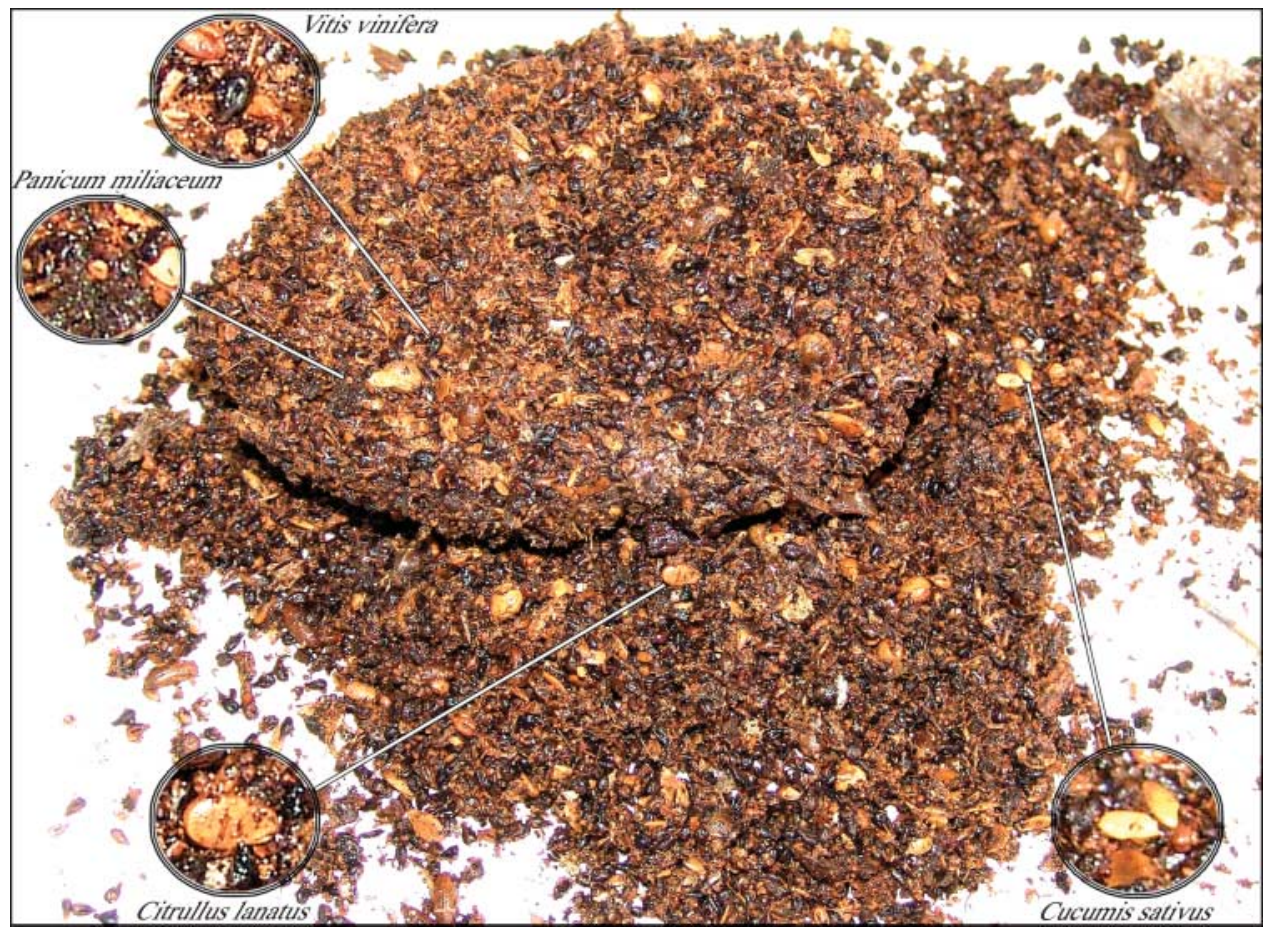

Figure 1. Clumps of excavated 15th-century seeds (King's Palace, Budapest, Hungary) after wet-sieving and floatation, with the most frequent species indicated.

(b')

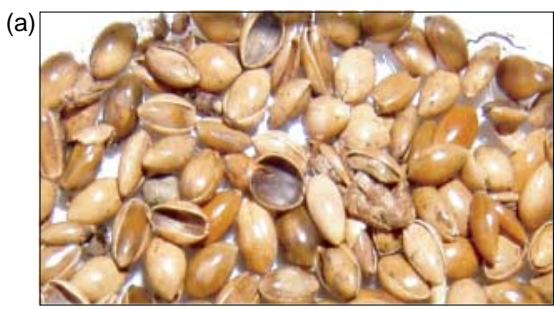

(b)

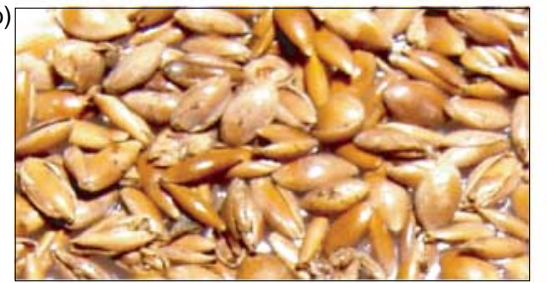

(c)
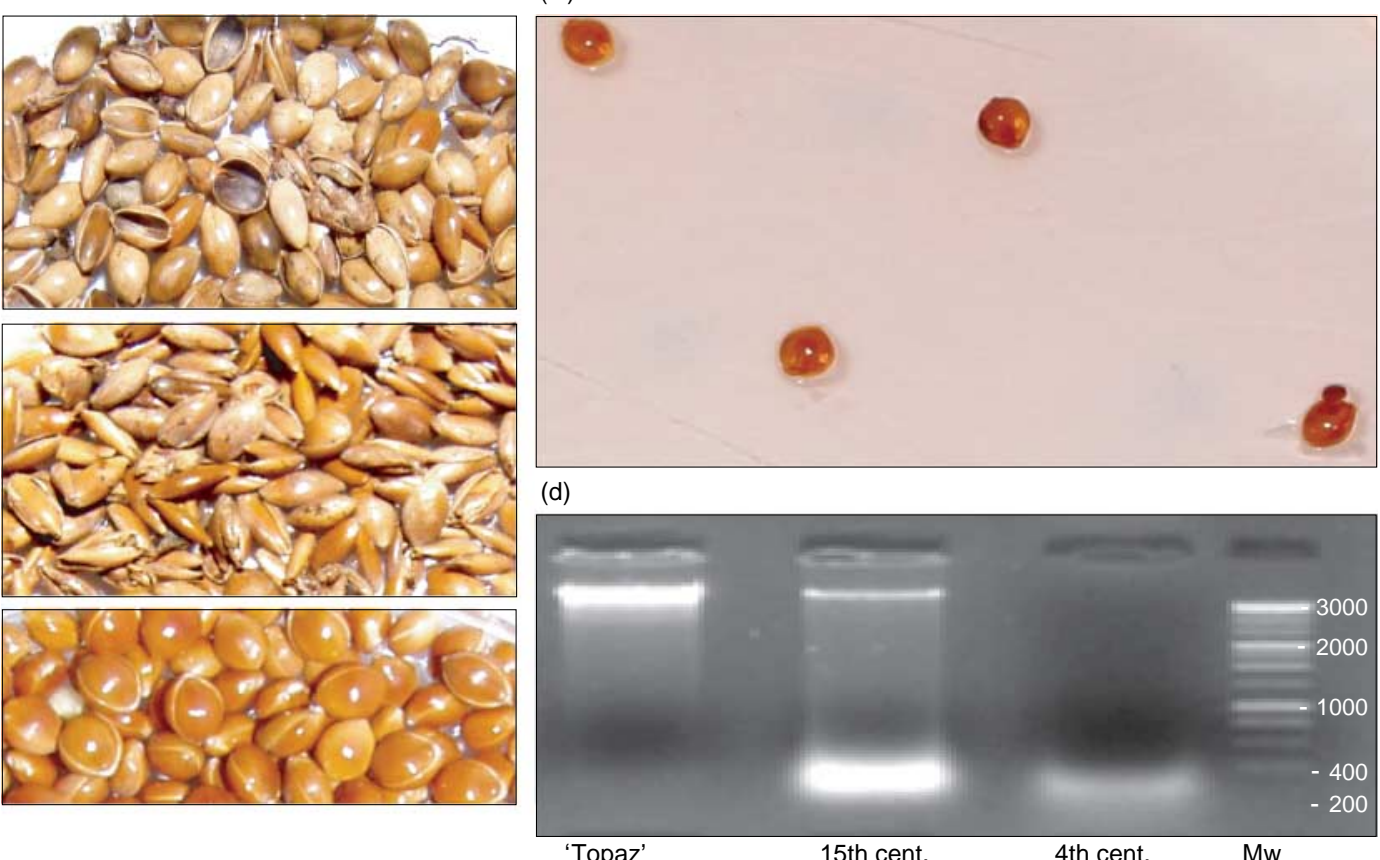

Figure 2. Surface sterilized grains (a)-(c), and DNA samples (d) (with molecular weight, Mw, markers in bp) of common millet (Panicum miliaceum) excavated from the 4th century (a) and 15th century (b), rehydrated and swelling on aseptic tissue culture medium $\left(\mathrm{b}^{\prime}\right)$; and compared to modern millet cultivar 'Topaz' (c). 
Table 2. List and numbers (pieces) of identified seed remains (\#) of excavated plant species (1-195) in the 15th-century site (King's Palace, Budapest, Hungary)

\begin{tabular}{|c|c|c|c|c|c|c|c|c|}
\hline \multicolumn{2}{|c|}{ Latin name } & \multirow{2}{*}{$\frac{\#}{2}$} & \multicolumn{2}{|c|}{ Latin name } & \multirow{2}{*}{$\begin{array}{c}\# \\
39\end{array}$} & \multicolumn{2}{|c|}{ Latin name } & \multirow{2}{*}{$\begin{array}{c}\# \\
1025\end{array}$} \\
\hline 1 & Adonis aestivalis & & 69 & Galium mollugo & & 137 & Prunus fruticosus & \\
\hline 2 & Aethusa cynapium & 2 & 70 & Galium spurium & $169^{*}$ & 138 & Prunus mahaleb & 425 \\
\hline 3 & Agrostemma githago & 5516 & 71 & Glaucium corniculatum & 3 & 139 & Prunus padus & 7 \\
\hline 4 & Ajuga chamaepitys & 335 & 72 & Glechoma hederacum & 1 & 140 & Prunus persica & 362 \\
\hline 5 & Amaranthus lividus & 1243 & 73 & Heliotropium eитораеит & 1 & 141 & P. spinosa (macrocarpa) & 35 \\
\hline 6 & Anethum graveolens & 1622 & 74 & Hordeum murinum & 1 & & P. spinosa (macrocarpa) & 50 \\
\hline 7 & Anthemis tinctora & 2 & 75 & Hordeum vulgare & $8^{*}$ & & P. spinosa - a & 194 \\
\hline 8 & Apium graveolens & 12 & 76 & Humulus lupulus & 223 & & P. spinosa - b & 216 \\
\hline 9 & Arctium minus & 2 & 77 & Hyoscyamus niger & 4 & 142 & Punica granatum & 171 \\
\hline 10 & Arctium tomentosum & 1 & 78 & Hypericum perforatum & 12 & 143 & Pyrus communis & 6682 \\
\hline 11 & Avena sativa & $51^{*}$ & 79 & Juglans regia & 1609 & 144 & Pyrus sp. & 5290 \\
\hline 12 & Ballota nigra & 1 & 80 & Lamium amplexicaule & 26 & 145 & Ranunculus repens & 117 \\
\hline 13 & Brassica campestris & 21 & 81 & Lamium purpureum & 1 & 146 & Raphanus raphanistrum & 19 \\
\hline 14 & Brassica oleracea & 34 & 82 & Laserpitium latifolium & 1 & 147 & Raphanus sativus & 52 \\
\hline 15 & Bromus secalinus & $8^{*}$ & 83 & Lathyrus sp. & 3 & 148 & Reseda lutea & 1113 \\
\hline 16 & Bryonia alba & 1 & 84 & Lens culinaris & $1^{*}$ & 149 & Rosa canina & 36 \\
\hline 17 & Bupleurum rotundifolium & 1120 & 85 & Leontodon autumnalis & 1 & 150 & Rosa sp. & 584 \\
\hline 18 & Calamintha acinos & 9 & 86 & Lepidium campestre & 3 & 151 & Rubus caesius & 24,579 \\
\hline 19 & Camelina sp. & 97 & 87 & Linum austriacum & 3 & 152 & Rubus fruticosus & 2756 \\
\hline 20 & Campanula sp. & 1 & 88 & Linum usitatissimum & 4 & 153 & Rubus idaeus & 1320 \\
\hline 21 & Cannabis sativa & 1618 & 89 & Lithospermum offinale & 58 & 154 & Rumex acetosella & 8 \\
\hline 22 & Carduus acanthoides & 4 & 90 & Lychnis flos-cuculi & 2 & 155 & Salvia nemorosa & 2 \\
\hline 23 & Carex elata & 1 & 91 & Lycopus europaeus & 12 & 156 & Salvia verticillata & 104 \\
\hline 24 & Carex flava & 2 & 92 & Malus domestica & 33,724 & 157 & Sambucus ebulus & 168 \\
\hline 25 & Carex hirta & 32 & 93 & Malus silvestris & 21 & 158 & Sambucus nigra & 194 \\
\hline 26 & Carex pallescens & 17 & 94 & Malus sp. & $8141^{*}$ & 159 & Saponaria officinalis & 14 \\
\hline 27 & Carex silvatica & 1 & 95 & Malva alcea & 1 & 160 & Schoenoplectus lacustris & 14 \\
\hline 28 & Carex tricarpellata & 3 & 96 & Malva neglecta & 1 & 161 & Sch. tabernaemontani & 2 \\
\hline 29 & Carex vulpina/muricata & 24 & 97 & Marrubium peregrinum & 1307 & 162 & Schoenus nigricans & 2 \\
\hline 30 & Castanea sativa & 352 & 98 & Marrubium vulgare & 3 & 163 & Scirpus maritimus & 1 \\
\hline 31 & Caucalis platycarpos & 1 & 99 & Matricaria inodora & 12 & 164 & Secale cereale & $208^{*}$ \\
\hline 32 & Centaurea cyanus & 6 & 100 & Melandrium noctiflorum & 4 & 165 & Setaria lutescens & 643 \\
\hline 33 & Centaurea jacea & 560 & 101 & Mespilus germanica & 760 & 166 & Setaria viridis/verticillata & 37,001 \\
\hline 34 & Centaurea scabiosa & 4 & 102 & Morus nigra & 39,670 & 167 & Silene alba & 151 \\
\hline \multirow[t]{2}{*}{35} & Cerealia & 1 & 103 & Muscari comosum & 2 & 168 & Silene dioica & 1 \\
\hline & Cerealia & $39^{*}$ & 104 & Nepeta cataria & 3 & 169 & Silene vulgaris & 3 \\
\hline 36 & Cerinthe minor & 16 & 105 & Neslea paniculata & 52 & 170 & Sinapis alba & 1 \\
\hline 37 & Chenopodium album & 30,457 & 106 & Ocimum basilicum & 1 & 171 & Sinapis arvensis & 733 \\
\hline 38 & Chenopodium ficifolium & 2 & 107 & Origanum vulgare & 2 & 172 & Solanum dulcamara & 57,962 \\
\hline 39 & Chenopodium hybridum & 708 & 108 & Orlaya grandiflora & 33 & 173 & Solanum nigrum & 811 \\
\hline 40 & Chrysanth. eucanthemum & 1 & 109 & Panicum miliaceum & 955,497 & 174 & Sonchus asper & 1 \\
\hline 41 & Chrysanthemum segetum & 3 & & Panicum miliaceum & $1442^{*}$ & 175 & Sonchus oleraceus & 20 \\
\hline 42 & Cichorium intybus & 46 & 110 & Papaver dubium & 3 & 176 & Sorbus domestica & 1276 \\
\hline 43 & Circaea lutetiana & 1 & 111 & Papaver rhoeas & 57 & 177 & Stachys annua & 847 \\
\hline 44 & Citrullus lanatus & 54,415 & 112 & Papaver somniferum & 359,981 & 178 & Stachys arvensis & 43 \\
\hline 45 & Conringia orientalis & 1 & 113 & Pastinaca sativa & 60 & 179 & Stellaria holostea & 1 \\
\hline 46 & Convolvulus arvensis & 1 & 114 & Physalis alkakengi & 5517 & 180 & Stellaria media & 147 \\
\hline 47 & Coriandrum sativum & 51 & 115 & Picris hieracioides & 5 & 181 & Taraxacum officinale & 2 \\
\hline 48 & Cornus mas & 1936 & 116 & Piper nigrum & 1046 & 182 & Thalictrum flavum & 2 \\
\hline 49 & Corylus avellana & 541 & 117 & Pisum sativum & $2^{*}$ & 183 & Thalictrum minus & 16 \\
\hline 50 & Cucumis melo & 28,117 & 118 & Plantago major & 1 & 184 & Thlaspi arvense & 415 \\
\hline 51 & Cucumis sativus & 11,783 & 119 & Poaceae & 1534 & 185 & Tilia sp. & 2 \\
\hline 52 & Cuscuta europaea & 4 & 120 & Polygonum aviculare & 618 & 186 & Trifolium arvense & 1 \\
\hline 53 & Cydonia oblonga & 351 & 121 & Polygonum mite/minus & 1 & 187 & Triticum aestivum & 221 \\
\hline 54 & Cyperus fuscus & 1 & 122 & Polygonum persicaria & 49 & & Triticum aestivum & $3^{*}$ \\
\hline 55 & Cyperus longus & 1 & 123 & Potentilla erecta & 1 & 188 & Urtica dioica & 1 \\
\hline 56 & Daucus carota & 71 & 124 & Potentilla reptans & 2 & 189 & Vaccaria pyramidale & 328 \\
\hline 57 & Dianthus sp. & 3 & 125 & Primula elatior & 1 & 190 & Valerianella dentata & 51 \\
\hline
\end{tabular}


Table 2. Continued

\begin{tabular}{|c|c|c|c|c|c|c|c|c|}
\hline \multicolumn{2}{|c|}{ Latin name } & \multirow{2}{*}{$\begin{array}{r}\text { \# } \\
1\end{array}$} & \multicolumn{2}{|c|}{ Latin name } & \multirow{2}{*}{$\begin{array}{r}\# \\
38\end{array}$} & \multicolumn{2}{|c|}{ Latin name } & \multirow{2}{*}{$\frac{\#}{10}$} \\
\hline 58 & Diplotaxis muralis & & 126 & Prunus amygdalus & & 191 & Viburnum lantana & \\
\hline 59 & Echinochloa crus-galli & 4 & 127 & Prunus armeniaca & 6 & 192 & Viburnum opulus & 15 \\
\hline 60 & Eleocharis palustris & 5 & 128 & Prunus avium & 9783 & 193 & Vicia hirsuta & 16 \\
\hline 61 & Euphorbia cyparissias & 43 & 129 & Prunus cerasifera & 259 & 194 & Vitis vinifera & 241,231 \\
\hline 62 & Euphorbia exigua & 1 & 130 & Prunus cerasus & 13,368 & 195 & Xanthium italicum & 1 \\
\hline 63 & Euphorbia platyphyllos & 6 & 131 & Prunus domestica italica & 5 & & & \\
\hline 64 & Fallopia convolvulus & 3275 & 132 & P. domestica institia & 14 & & Food remains (bread) & $2^{*}$ \\
\hline 65 & Ficus carica & 278,459 & 133 & P. domestica syriaca & 15 & & Food remains (gruel) & $32^{*}$ \\
\hline 66 & Fragaria vesca & $1,056,154$ & 134 & P. domestica oeconomica & 651 & & Food remains (cooked) & $12^{*}$ \\
\hline 67 & Galeopsis ladanum & 1 & 135 & P. domestica Juliana & 736 & & & \\
\hline 68 & Galium aparine & 60 & 136 & P. domestica oxicarpa & 111 & & Total & $3,293,623$ \\
\hline
\end{tabular}

${ }^{*}$ Indicates carbonized samples.

contaminated grains infected by fungi and bacteria were eliminated from further analyses.

\section{DNA extraction}

Aseptic seed remains were ground in an aseptic mortar with liquid nitrogen in a laminar air-flow cabinet. aDNA was extracted by the CTAB (cetyltrimethylammonium bromide) method in batches, according to Yang (1997), Cooper and Poinar (2000) and Biss et al. (2003). Seed DNA of modern cultivars (0.1 g dry weight) was also extracted in CTAB buffer, followed by an RNase-A treatment (Sigma, St. Louis, Missouri, USA) for $30 \mathrm{~min}$ at $37^{\circ} \mathrm{C}$. To avoid crosscontamination, ancient and modern samples were handled in separate laboratories using different laminar air-flow cabinets, pipettes, autoclaved tubes, mortars, pestles and thermocyclers, according to Szabo et al. (2005). The quality and quantity of extracted DNA were measured $(2 \mu \mathrm{l})$ by a NanoDrop ND-1000 UV-Vis spectrophotometer (NanoDrop Technologies, Delaware, USA; BioScience, Budapest, Hungary). DNA samples were adjusted to a concentration of $30 \mathrm{ng} / \mu \mathrm{l}$ with double-distilled water $\left(\mathrm{ddH}_{2} \mathrm{O}\right)$ and subjected to polymerase chain reaction (PCR) amplification according to Lagler et al. (2005).

\section{PCR primers}

Four nuclear simple sequence repeats (SSRs) at $g \ln 4$, sh1, rps 28 and rps15 loci and a ribosomal mtDNA at the 18S-5S rDNA locus were amplified (Table 1).

\section{PCR}

A minimum of two independent DNA preparations from each sample was used for PCR, following the basic protocols of amplified fragment length poly- morphism (AFLP) (Vos et al., 1995), SSR (Chin et al., 1996) and mtDNA (Petit et al., 1998). Each successful reaction with scorable bands was repeated at least twice. Negative controls including aDNA-free, primerfree, Taq-free and water were included in PCR runs.

\section{SSR analysis}

SSR fragments were separated $(2 \mu \mathrm{l})$ by an automatic laser fluorometer (ALFexpress II DNA Analyser; Amersham Bioscience, Uppsala, Sweden; AP, Budapest, Hungary), according to Roder et al. (1998). Polyacrylamide gel electrophoresis (PAGE; 24\% w/v) with a short thermoplate and 40-sample capacity, was run at $850 \mathrm{~V}, 50 \mathrm{~mA}, 50 \mathrm{~W}$ at $50^{\circ} \mathrm{C}$ for $120 \mathrm{~min}$, prior to UV-linkage for $15 \mathrm{~min}$. One primer of each primer pair was labelled with Cy5 fluorescent dye at the $5^{\prime}$-end (Sigma). For sequencing, SSR and mtDNA fragments $(15 \mu \mathrm{l})$ were run and cut out from agarose $(1.6 \% \mathrm{w} / \mathrm{v})$ gels and purified in a spin column (Sigma). mtDNA fragments were digested with the restriction endonuclease $\mathrm{Mbo}$ I to facilitate sequencing, according to the manufacturer's protocol (Fermentas-Biocenter, Szeged, Hungary).

\section{AFLP analysis}

Undiluted aDNA samples $(5.5 \mu \mathrm{l})$ were subjected to fAFLP (fluorescent AFLP) analysis, following the method of Vos et al. (1995) with modifications (Cresswell et al., 2001; Skøt et al., 2002). For digestion-ligation reactions, pairs of Eco RI-Mse I restriction endonucleases (REases) were used. The sequences of the preselective primer pairs were: $E c o-A$ (gac tgc gta cca att c-a) and Mse-C (gat gag tcc tga gta ac). For selective amplification, 24 primer combinations were used with 'JOE' (green) fluorescent-labelled *Ecoprimers. In primer combinations $1-12$, the primer 


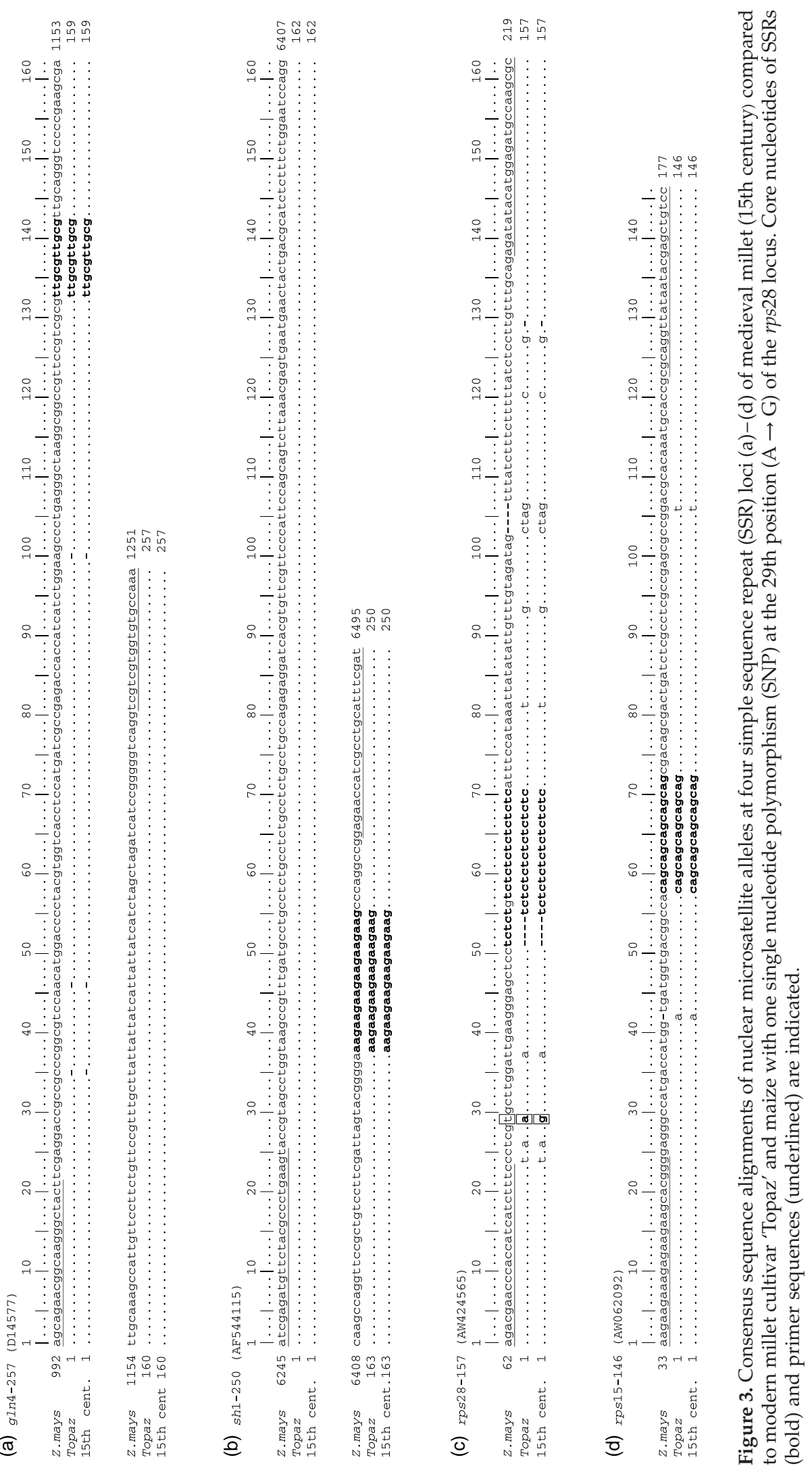


MseCAC was combined with labelled primers of * Eco aaa, -aac, -aag, -aat, -aca, -acc, -agg, -act, -aga, -agc, -agg, -agt. In primer combinations 13-24, the labelled primer *EcoAGT was combined with primers of Mse -caa, -cag, -cat, -cca, -ccc, -ccg, -cct, -cga, -cgc, -cgg, -cgt, -cta according to Gyulai et al. (2005). All oligonucleotides were supplied by Sigma Genosys (St. Louis, Missouri, USA), and enzymes were obtained from Roche Diagnostics (Basel, Switzerland). PCR-amplified AFLP fragments were subsequently denatured at $98^{\circ} \mathrm{C}$ for $5 \mathrm{~min}$, and directly forwarded to an ABI PRISM 3100 Genetic Analyzer (Applied Biosystems, Foster City, California, USA), using a G5 filter set in two repetitions, and analysed by ABI PRISM Genotyper 3.7 NT software at the range of 150-600 bp.

\section{Fragment recovery}

AFLP samples were loaded $(8 \mu \mathrm{l})$ on to a $4.5 \%(\mathrm{w} / \mathrm{v})$ PAGE sequencing gel (Sequi-Gen GT, Biorad, Hercules, California, USA) and run for $1.5 \mathrm{~h}$ at $100 \mathrm{~W}$ (2090 V, $48 \mathrm{~mA})$, followed by silver staining (Promega, St. Louis, Missouri, USA). AFLP fragments recovered from gels were either reamplified (using $1 \mu \mathrm{l}$ in a PCR reaction with non-labelled primer pairs of EcoAGTMseCAC and EcoAGT-MseCAA), or cloned into pGEM-T Easy Vector System II, and transformed into a Jm109 competent cell (Promega). Inserts were cut out by Eco RI.

\section{Sequencing}

Fragments were subjected to automated fluorescent DNA sequencing (ABI PRISM 3100 Genetic Analyzer) and sequenced from both directions. Sequences were analysed by the computer program ChromasPro version 1.11 (Technelysium Pty Ltd, Tewantin, Queensland, Australia). Sequence alignments were analysed by BioEdit Sequence Alignment Editor (North Carolina State University, Raleigh, North Carolina, USA) and also by GCG-10 (Genetics Computer Group, Oxford Molecular Group Inc., Madison, Wisconsin, USA; Wisconsin Package, Version 10.3) software programs. BLAST (Basic Local Alignment Search Tool) analysis was carried out using the computer program from NCBI (National Center for Biotechnology Information, Bethesda, Maryland, USA).

\section{Results}

Excavation sites from the 4th century (Mongolia) and 15th century (Hungary) contained a great number of plant remains, including grains of common millet $(P$. miliaceum). The medieval site (Hungary) contained about 3 million plant remains of 195 species (Table 2), 


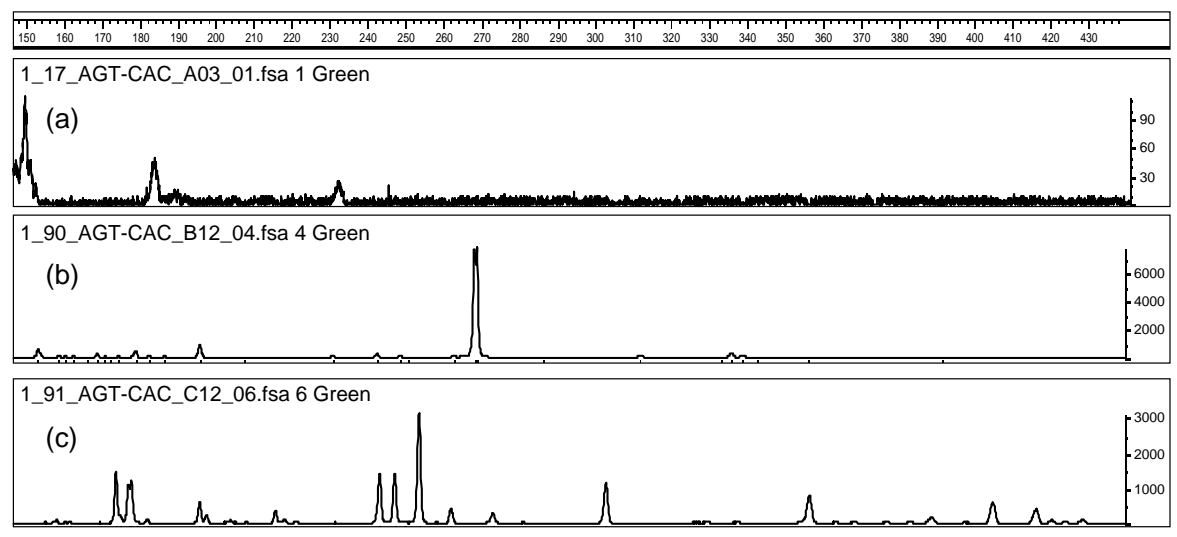

Figure 5. Samples of amplified fragment length polymorphism (AFLP) (EcoAGT-MseCAC) fragment analysis (150-430 bp, with relative intensities of 30-6000) in the 4th-century (a) and 15th-century common millet (Panicum miliaceum) (b), compared to the modern millet cultivar 'Topaz' (c).

including 955,497 grains of common millet (Fig. 1). Intact grains from both sites were separated from damaged grains under a microscope. The 4th-century grains showed greater damage (Fig. 2). The ancient grains showed shrunken forms (Fig. 2) with a major loss of kernel; nevertheless, intact grains selected from the medieval sample showed swelling upon rehydration on tissue culture media after surface sterilization and incubation (Fig. 2). Aseptic seeds were separated and incubated individually (Fig. 2). Because the single grains had a low quantity of aDNA, 16 intact grains from 50 seed remains of 4th-century millet were pooled, and 78 intact grains from 150 seed remains of 15th-century millet were pooled to extract DNA, according to Michelmore et al. (1991).

SSR alleles at four loci $-g \ln 4(257 \mathrm{nt}), \operatorname{sh} 1(250 \mathrm{nt})$, rps28 (157 nt) and rps15 (146 nt) - were amplified in the 15th-century millet and the modern millet cultivar 'Topaz'. No SSR amplification was observed in the 4thcentury sample. The medieval SSR fragments showed identical alignments with modern millet and maize sequences, with only one SNP (single nucleotide polymorphism) at the 29th position $(\mathrm{A} \rightarrow \mathrm{G})$ of the rps28 locus (Fig. 3).
When SSR sequences of medieval and modern millet were compared to maize (Zea mays) (NCBI database), three indels (insertion and deletions) and SNPs were observed in the $g \ln 4$ allele of millets. There was consensus between the millets and maize at the sh 1 locus. In the rps 28 locus of millets, a (ct) $)_{2}$ dinucleotide repeat deletion of the core sequence of SSR and several SNPs were observed compared to maize (Fig. 3). In the rps15 locus an insertion of A at the 42 nd position, and a $G \rightarrow$ T nucleotide substitution (transversion) at the 106th position, were detected in the millets compared to maize (Fig. 3).

Of the organelle-specific primer pairs applied [chloroplast DNA (cpDNA): $\operatorname{trn} \mathrm{H}, \operatorname{trn} \mathrm{K}, r p o \mathrm{C} 2$ and psbC; and mtDNA: nad1B, nad1C, cox II and cob] from the collection of Petit et al. (1998) (data not shown), one of the 18S-5S ribosomal mtDNA primer pairs (Al-Janabi et al., 1994) recognized a template in the medieval and modern millets. Sequence analysis of the restricted fragment Mbo I ( $571 \mathrm{bp})$ did not detect any nucleotide changes between the medieval and modern common millet (Fig. 4). No organelle aDNA was amplified in the 4th-century sample.

Table 3. Total numbers, \%, and degradation (degr. \%) of the fluorescent amplified fragment length polymorphism (fAFLP) fragments of common millets (4th and 15th centuries), compared to modern millet cultivar 'Topaz'. The selective AFLP primer combinations are: MseCAC combined with (a) EcoAAT*, (b) EcoACC*, and (c) EcoAGT*; and EcoAGT* combined with (d) MseCAA, (e) MseCAG, (f) MseCAT, (g) MseCCC, (h) MseCCT, (i) MseCGA, (j) MseCGC and (k) MseCTA

fAFLP fragment number/selective primer pairs (a) to $(\mathrm{k}) \quad$ Total

\begin{tabular}{lcccccccccccrrrr} 
& (a) & (b) & (c) & (d) & (e) & (f) & (g) & (h) & (i) & (j) & (k) & No. & $\%$ & degr.\% \\
\hline 4th century & - & - & 2 & - & - & - & - & - & - & - & - & 2 & 0.8 & 99.2 \\
15th century & 10 & 18 & 24 & 34 & 29 & 12 & 16 & 5 & 5 & 3 & 2 & 158 & 60.0 & 40.0 \\
'Topaz' & 32 & 23 & 38 & 42 & 34 & 33 & 18 & 17 & 7 & 4 & 16 & 264 & 100.0 & 0 \\
\hline
\end{tabular}

*Indicates a fluorescent-labelled primer. 


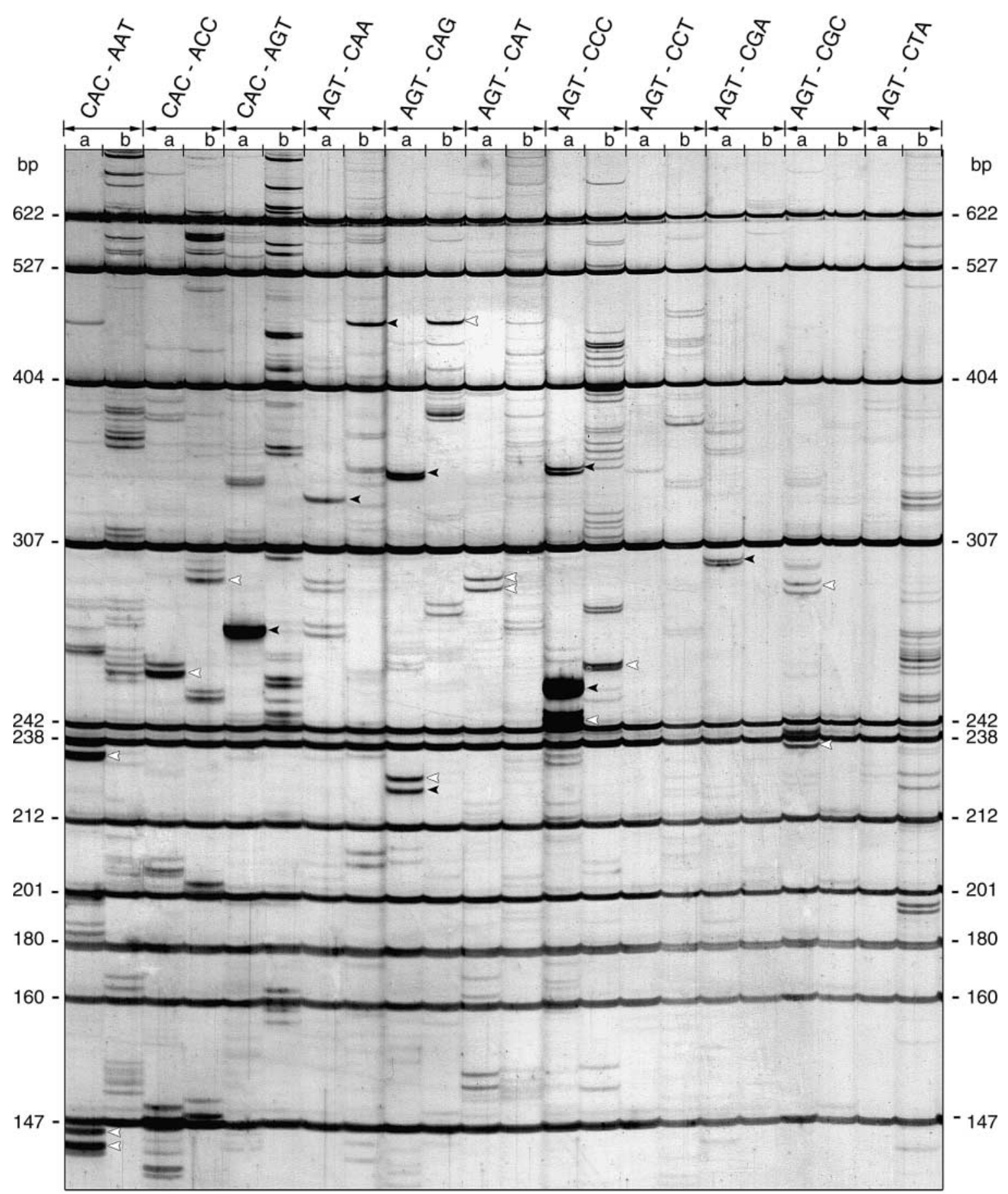

Figure 6. Polyacrylamide gel electrophoresis (PAGE) analysis of amplified fragment length polymorphism (AFLP) fragments of common millet (Panicum miliaceum) excavated from the 15th-century site (a) compared to the modern cultivar 'Topaz' (b). DNA molecular weight markers (622 to $147 \mathrm{bp}$ ), fragments recovered (white arrowheads) and sequenced (black arrowheads) are indicated.

\section{AFLP analysis}

Eleven of the 24 selective primer pairs produced sharp AFLP patterns in the samples (Fig. 5). The 4th-century sample revealed only two fragments $(85 \mathrm{bp}$ and $230 \mathrm{bp})$, both amplified by the EcoAGT-MseCAC primer pair; 158 AFLP bands were amplified in the 15th-century sample compared to the 264 AFLP bands 
(1) ${ }_{E c o} \mathrm{AGT}-{ }_{\text {Mse }} \mathrm{CAG}-225-15_{\text {th }}$ cent.

gactgcgtaccaattcagtgtgaatgacggggatgaccggatcaaatcgattagaggtatggaagggattgtaaggcagatcagaaggctgtcg ccgaagacggatatttgcttcgtctatacggcagccgacaagaatctggccgatccgttaccgttcaatatagccgttcatgaagaagtagctg cccattacgctattcccgctgttactcaggactcatc

(2) ${ }_{E c o} \mathrm{AGT}-{ }_{M s e} \mathrm{CCC}-252-15_{\text {th }}$ cent.

gactgcgtaccaattcagtatccggataccaactatccctctcgtaatggttagattccatttggggtcgctgagtcatttcctgatacaagaa cagaccaggcacgatcatgtacggggaggagctgcgtttgttctcaaatgccgctgctcctcttccgcggagcgcctctgtacccaaatgctgt aggcggccatcccogatacacattccatatcgataaaccaaggaggggttactcaggactcatc

(3) ${ }_{E c o} \mathrm{AGT}-{ }_{M s e} \mathrm{CAC}-272$ - $15_{\text {th }}$ cent. - (BAB04200)

gactgcgtaccaattcagtaggcctacctctttgacgacgagatacgttggaatcaagccaccgctgaaaaacatcgtaataacgaacgtcagc atcaagacacgcccgtagggcagtacttttttggataacgcataagcagccaatatcgtcaacgccatactgaccaatgtgccgacaaccgtaa taaacacggaattggtaaaggagtaaagaactgcttgttcgtaagcacatactcaaacgacatcgtgttactcaggactcatc

(4) ${ }_{E c o} \mathrm{AGT}-{ }_{M s e} \mathrm{CGA}-298-15$ th cent.

gactgcgtacccaattcagtagaaagacagccaagacaagtccttcaggcatattctgtgccccgatggatatcgcgaccataggacctaaagc ttcattgctactcgcataactaaatcctgtgctgagtccctccgggatgttatggataaatagagctataataaccaataaagatttggcatca aaggatttgataccagaatcattctccacatctacatgaggaatattcttctcaataatatccagaacaacaataccaatcacaaaacctatcg ttactcaggactcatc

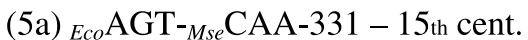

gactgcgtacccaattcagtcaaaaatcaacgtgcagttgaagagcgcgtgcgcgaagcactgcaaatggatcgcgcccgcgtgcaagttggcc gtatttcacgctttggcttgctggagatgtctcgccagcgtctgcgcccttcattgaacgaaacctcaggtcacgtctgcccgcgctgcaacgg ccaaggcaccattcgcggcacccgctcaatcgcgctggccatcttgcgtatgctggaagaagaagcgcagaaagagcgcagctcagaagtgcgc gccetgacgccagtcgccgtcgcaagcttcttgttactcaggactcatc

(5b) ${ }_{E c o}$ AGT- ${ }_{M s e}$ CAA-462 - cv. Topaz - (AF050455)

gactgcgtaccaattcagtcgcgctttggaggacaaggcggaggatatccgcagagtcaacagaatcaacgaactccacagcagcctcagcgct tcaaccagcagactcagcgcaactccaacccgcaaccgtaccgttcaggctatgccacgggtgcaccagtgcggaccaacaatccagtcacacc ggtccaacccaacggctgtttcaaatgtggagaactggggcattatgctaacaactgcccgaagcgtaacrtgcagactcctcagaatcagagg aacagtggacagaggcagactcctcagcagcagcagccgcgcaacagcaaccagacaccactgggcaacagaggtcaacagaactacgtgcgcg gaaagggtgaatcatgtggctgcagaaacagctgaagaggctcccgatgttgtgctcggtacgttccttgttactcaggactcatc

(6) ${ }_{E c o} \mathrm{AGT}-{ }_{M s e} \mathrm{CAG}-344-15_{\text {th }}$ cent.

gactgcgtacccaattcagtacaacgaatttctctcctctattcctggcatcagccagctcactcttctggtcatttgaaggcgtaacgatgat gtattcatccagattaggaggtatggattgcagatcagccaggtccaaaaaccggatggaaacaccacgttgatgtgcttcatccctcatgccg tccatcatctccgaaagggtagcatatacactgcgatgtggattgcataaccagacattcaacgtcgctgttgacgggttctcgtgctctttag caatttcccggttggacacatacgttccttacctttcttcgctgttactcaggactcatc

(7) ${ }_{E c o} \mathrm{AGT}-{ }_{M s e} \mathrm{CCC}-345-15$ th cent.

gactgcgtacccaattcagtgtgacgctgtggggcaagaacctcaccaacaagcactacgcaagccgcgcggtcgattttggacaactgggatt ttcgaccgtcagtttcggtgatcccagaaccttcggcctcacgctggacgctcaattctaggaacgaatgccatttggtcgccgcatcaagttt atgcggcgaccagggctcatacttgttgggtgtgcaaagctaatcatgcggaaattgccagaaatctgccatttacaaacacacgagacacacg ctcaaaaagcgctctcgcttcagttctttcacttgaatgtcggggttactcaggactcatc

Figure 7. Sequence data of amplified fragment length polymorphism (AFLP) fragments of 15th-century common millet (Panicum miliaceum) (1)-(7), compared to the modern millet cultivar 'Topaz' (5b). Primer sequences of selective primer pairs of EcoAgactgcgtaccaattc-axx and the complementary sequence of $M s e C$-gatgagtcctgagtaa-cxx are underlined.

detected in the modern common millet cultivar 'Topaz'. The average number of AFLP fragments per selective primer pair ranged from 0.2 (4th-century millet) and 14.4 (15th-century millet) to 24 ('Topaz'). The selective primer pair EcoAGT-MseCAA was the most effective combination, generating 34 and 42 AFLP fragments in the 15th-century millet and 'Topaz', respectively (Table 3).

Twenty-one AFLP fragments were recovered from a PAGE gel (Fig. 6), and eight of them revealed identical sequences after either reamplification or cloning (Fig. 7). BLAST analysis revealed that one fragment (EcoAGT-MseCAC-272) from the 15thcentury millet showed significant similarity with the universal Ugpe, an ABC-type transporter (permease) gene (NCBI, BAB04200) (Fig. 7). A fragment (EcoAGT-MseCAA-462) from the modern millet cultivar 'Topaz' showed significant similarity with the gypsy/Ty3-type retrotransposon (NCBI, AF050455). AFLP fragments amplified by the same 
primer pair (EcoAGT-MseCAA) in the medieval and modern millet (5a and $5 b$ in Fig. 7) did not show sequence homology, when amplified from different loci of their genomes. The two AFLP fragments from the 4th-century millet had such low intensities that further fragment purification was not successful.

\section{Discussion}

Common millet grains of the 15th-century site used in the present study appeared to be extremely well preserved due to anaerobic conditions in the slime of a deep well covered by water, apparently used as dusthole in the Middle Ages (Nyekhelyi, 2003). These seeds looked intact, but were incapable of germinating: the half-life longevity of P. miliaceum is reported to be c. 12 years (Priestley, 1986). Nevertheless 15thcentury grains showed swelling on tissue culture medium (Fig. 2) by water uptake, a primary event of seed germination (Bewley, 1997). Despite no germination, aseptic archaeo seeds, free of foreign DNA contamination, were obtained for further aDNA extraction and molecular analysis.

Agarose gel electrophoresis of the extracted total aDNA showed different degrees of degradation in the 4th- and 15th-century samples, compared to modern common millet (Fig. 2), probably due to hydrolytic and oxidative damage (Yang, 1997; Poinar et al., 2003; Pääbo et al., 2004). The quantities of aDNA extracted from two batches of 4 th-century grains $(0.083 \mathrm{~g}$ and $0.079 \mathrm{~g}$ produced $2.26 \mathrm{ng} / \mu \mathrm{l}$ and $1.97 \mathrm{ng} / \mu \mathrm{l}$ DNA, respectively) and those of 15th-century grains $(0.089 \mathrm{~g}$ and $0.090 \mathrm{~g}$ produced $8.82 \mathrm{ng} / \mu \mathrm{l}$ and $6.71 \mathrm{ng} / \mu \mathrm{DNA}$, respectively) were much lower than the DNA samples from the modern common millet cultivar 'Topaz' $(0.315 \mathrm{~g}$ and $0.371 \mathrm{~g}$ produced $417.3 \mathrm{ng} / \mu \mathrm{l}$ and $536.4 \mathrm{ng} / \mu \mathrm{l}$ DNA, respectively). The 15th-century aDNA showed less degradation than in 4th-century samples, with the presence of high molecular weight fragments (Fig. 2), probably not only because of the younger age of the samples, but also because of the cold, humid and anaerobic conditions in the medieval well. Successful aDNA extractions have been made from 400,000- to 10,000-year-old permafrost plant samples from Siberia (Willerslev et al., 2003). The extensive DNA degradation in the 4th-century millet aDNA was probably due to the arid continental climatic conditions at the surface excavations of the sandy soil site in Mongolia.

In theory, microsatellites, as highly species-specific probes (Toth et al., 2000), are optimal for aDNA analysis by excluding cross-reactions with contaminating microorganisms, or any ancient organisms and laboratory DNAs (Gugerli et al., 2005). SSR analysis has been applied to $c$. 100-year-old herbarium samples of common reed (Phragmites australis) to track plant invasion in North America (Saltonstall, 2003). Melon (Cucumis melo)-specific SSRs were used to identify an inodorus type melon recovered from the 15th century (Szabo et al., 2005). Allelic diversity of microsatellites was also reliably detected in aDNAs of 4000-year-old seagrass (Posidonia oceanica) (Raniello and Procaccini, 2002). However, the very fragmented aDNA (Fig. 2) of the 4th-century millet prevented SSR amplification in our study.

Unlike wheat, maize and Lolium, no database is available for common millet at present. Therefore, we selected maize-specific nuclear SSR markers for DNAfishing in the aDNA microsatellites. At the rps 28 locus, only one nucleotide change $(\mathrm{A} \rightarrow \mathrm{G})$ was observed between 15th-century millet and modern millet cultivar 'Topaz' at the 29th position (Fig. 3), which might be the reason for the post-mortem hydrolytic deamination of adenine (A) to hypoxanthine, which pairs with cytosine $(C)$ and can be read as guanine $(G)$ in the PCR amplification (Threadgold and Brown, 2003). Because the $A \rightarrow G$ transition is located in the middle of the SSR sequence, it does not seem to be an artefact caused by Taq polymerase, which adds an A to the amplified fragment at the $3^{\prime}$ end of the sequence (Hofreiter et al., 2001; Poinar et al., 2003).

The theoretical opposite nucleotide transition from $\mathrm{G}$ to $\mathrm{A}$ in modern millet compared to medieval millet, as the result of microevolution, seems to be unlikely, since the relatively constant rate of mutation in evolution is longer than 600 years, even in crops that have been under accelerated evolution by selection pressure (Bromham and Penny, 2003). To compare, the mutation rate of human SSRs is about $10^{-3}$ to $10^{-5}$ per gamete (Bowcock et al., 1994). Nevertheless, nuclear SSRs of aDNA of medieval melon (Cucumis melo), excavated from the same site as the millet in the present study, showed a high number of indels (13) in a 1383-bp-long sequence of eight microsatellite loci (Szabo et al., 2005). Our results might indicate a more stable monocotyledonous millet genome compared to dicotyledonous melon, or more accelerated post-mortem aDNA degradation in the high-protein-containing melon seeds than in the high-carbohydrate-containing millet grains (Poinar and Stankiewicz, 1999).

Organelle mtDNA at the 5S-18S rDNA locus was amplified in the medieval sample, but not in the 4thcentury sample. The Mbo I-571 fragment of the medieval sample revealed consensus sequence alignments with the modern cultivar 'Topaz' (Fig. 4), without SNPs, as expected. Multiple copy aDNA fragments - such as the highly conserved mtDNA, cpDNA and rDNA - were also reported to be highly amplified compared to double-copy $(2 n)$ nuclear aDNA sequences (Deguilloux et al., 2002; Gugerli et al., 2005). The reason for the unsuccessful reactions in the rest of the organellespecific markers, including cpDNA $(\operatorname{trn} \mathrm{H}, \operatorname{trn} \mathrm{K}$, rpoC2 
and $p s b \mathrm{C}$ ) and mtDNA (nad1B, nad1C, cox II and $c o b$ ) (Petit et al., 1998), might be due to the expected long template fragments, which suggests a need for different protocols, such as long-PCR (Cheng et al., 1994; Cooper et al., 2001). Restorase DNA polymerase and GenomePlex WGA amplification (Sigma) have been used for amplification of DNA samples with limited quantities and qualities (Sun et al., 2005).

In the AFLP analysis, only one of the seven ALF fragments (Fig. 6) showed identical plant DNA sequences in the medieval sample. Nevertheless, only AFLP (Table 3) was successful in the fragment recovery from the 4th-century millet, compared to SSR or mtDNA. This result underlines the useful application of AFLP with high amplification capacity in archaeogenetics (Allaby and Brown, 2003).

To conclude, the incubation of archaeobotanical samples of common millet under aseptic conditions provided contamination-free seed samples for aDNA isolation. The aDNA degradation evaluated by AFLP was extensive in the 1600-year-old (4th-century) sample $(98.8 \%)$. In the 15th-century sample, with $40 \%$ AFLP degradation, a total of 2529-bp-long AFLP sequences was recovered. A further 1802-bp-long sequence was recovered from the 15 th-century millet at five nuclear SSR and mtDNA loci; these sequences are the first records in a Panicum database. Since only one SNP was observed in the 15th-century millet, at the rps28 SSR locus, this indicates a genetically stable Panicum genome with good preservation conditions at the medieval excavation site.

\section{Acknowledgements}

The authors wish to thank Dr L. Skøt, S. Heywood and K. Skøt for contributing in the AFLP analysis. The project was supported by Hungarian Scientific Research Group OTKA-M-04563, Organization for Economic Co-operation and Development grant OECD-JA00018642, the USA-Hungarian Fulbright Commission, and a Széchenyi Fellowship (SzÖ4/2003).

\section{References}

Al-Janabi, S.M., McClelland, M., Petersen, C. and Sobral, B.W.S. (1994) Phylogenetic analysis of organellar DNA sequences in the Andropogoneae: Saccharinae. Theoretical and Applied Genetics 88, 933-944.

Allaby, R.G. and Brown, T.A. (2003) AFLP data and the origins of domesticated crops. Genome 46, 448-453.

Bewley, J.D. (1997) Seed germination and dormancy. Plant Cell 9, 1055-1066.

Biss, P., Freeland, J., Silvertown, J., McConway, K. and Lutman, P. (2003) Successful amplification of rice chloroplast microsatellites from century-old grass samples from the Park Grass experiment. Plant Molecular Biology Reporter 21, 249-257.

Bowcock, A.M., Ruiz-Linares, A., Tomfohrde, J., Minch, E., Kidd, J.R. and Cavalli-Sforza, L.L. (1994) High resolution of human evolutionary trees with polymorphic microsatellites. Nature 368, 455-457.

Bromham, L. and Penny, D. (2003) The modern molecular clock. Nature Reviews Genetics 4, 216-224.

Brown, T.A. (1999) How ancient DNA may help in understanding the origin and spread of agriculture. Philosophical Transactions of the Royal Society of London, Series B 354, 89-98.

Cheng, S., Fockler, C., Barnes, W.M. and Higuchi, R. (1994) Effective amplification of long targets from cloned inserts and human genomic DNA. Proceedings of the National Academy of Sciences, USA 91, 5695-5699.

Chin, E.C.L., Senior, M.L., Shu, H. and Smith, J.S.C. (1996) Maize simple repetitive DNA sequences: Abundance and allele variation. Genome 39, 866-873.

Colosi, J.C. and Schaal, B.A. (1997) Wild proso millet (Panicum miliaceum) is genetically variable and distinct from crop varieties of proso millet. Weed Science 45, 509-518.

Cooper, A. and Poinar, H.N. (2000) Ancient DNA: Do it right or not at all. Science 289, 1139.

Cooper, A., Lalueza-Fox, C., Anderson, S., Rambaut, A., Austin, J. and Ward, R. (2001) Complete mitochondrial genome sequences of two extinct moas clarify ratite evolution. Nature 409, 704-707.

Cresswell, A., Sackville-Hamilton, N.R., Roy, A.K. and Viegas, B.M.F. (2001) Use of AFLP markers to assess genetic diversity of Lolium species from Portugal. Molecular Ecology 10, 229-241.

Deguilloux, M.-F., Pemonge, M.-H. and Petit, R.J. (2002) Novel perspectives in wood certification and forensics: dry wood as a source of DNA. Proceedings of the Royal Society of London, Series B 269, 1039-1046.

Gorman, C.F. (1969) Hoabinhian: a pebble-tool complex with early plant associations in Southeast Asia. Science 163, 671-673.

Gugerli, F., Parducci, L. and Petit, R.J. (2005) Ancient plant DNA: review and prospects. New Phytologist 166, 409-418.

Gyulai, F. (2000) Seed and fruit collections of the middle European plant species. Godollo, Hungary, St. Stephanus University.

Gyulai, G., Mester, Z., Kiss, J., Szeman, L., Heszky, L. and Idnurm, A. (2003) Somaclone breeding of reed canarygrass (Phalaris arundinacea L). Grass and Forage Science 58, 210-215.

Gyulai, G., Humphreys, M., Bittsánszky, A., Skot, K., Kiss, J., Skot, L., Gullner, G., Heywood, S., Szabo, Z., Lovatt, A., Radimszky, L., Roderick, H., Rennenberg, H., Abberton, M., Kómíves, T. and Heszky, L. (2005) AFLP analysis and improved phytoextraction capacity of transgenic gshI-poplar clones (Populus canescens L.) in vitro. Zeitschrift für Naturforschung 60c, 300-306.

Harlan, J.R. (1971) Agricultural origins: centers and noncenters. Science 174, 468-473.

Ho, P.-T. (1977) The indigenous origins of Chinese agriculture. pp. 413-418 in Reed, C.A. (Ed.) Origins of agriculture. Paris, Mouton Publishers. 
Hofreiter, M., Jaenicke, V., Serre, D., von Haeseler, A. and Pääbo, S. (2001) DNA sequences from multiple amplifications reveal artifacts induced by cytosine deamination in ancient DNA. Nucleic Acids Research 29, 4793-4799.

Keng, H. (1974) Economic plants of ancient north China as mentioned in Shih Ching (Book of Poetry). Economic Botany 28, 391-410.

Lagler, R., Gyulai, G., Humphreys, M., Szabo, Z., Horvath, L., Bittsanszky, A., Kiss, J., Holly, L. and Heszky, L. (2005) Morphological and molecular analysis of common millet (P. miliaceum) cultivars compared to an aDNA sample from the 15th century (Hungary). Euphytica 146, 77-85.

Michelmore, R.W., Paran, I. and Kesseli, R.V. (1991) Identification of markers linked to disease-resistance genes by bulked-segregant analysis: a rapid method to detect markers in specific genomic regions by using segregating populations. Proceedings of the National Academy of Sciences, USA 88, 9828-9832.

Nyekhelyi, B.D. (2003) Monumenta historica Budapestinensia XII. Hungary, Historical Museum of Budapest.

Pääbo, S., Poinar, H., Serre, D., Jaenicke-Despres, V., Hebler, J., Rohland, N., Kuch, M., Krause, J., Vigilant, L. and Hofreiter, M. (2004) Genetic analyses from ancient DNA. Annual Review of Genetics 38, 645-679.

Petit, R.J., Demesure, B. and Dumolin, S. (1998) cpDNA and mtDNA primers in plants. pp. 256-261 in Karp, A.; Isaac, P.G.; Ingram, D.S. (Eds) Molecular tools for screening biodiversity. London, Chapman \& Hall.

Poinar, H.N. and Stankiewicz, B.A. (1999) Protein preservation and DNA retrieval from ancient tissues. Proceedings of the National Academy of Sciences, USA 96, 84268431.

Poinar, H.N., Kuch, M., McDonald, G., Martin, P. and Pääbo, S. (2003) Nuclear gene sequences from a late Pleistocene sloth coprolite. Current Biology 12, 1150-1152.

Priestley, D.A. (1986) Seed aging: Implication for seed storage and persistence in the soil. Ithaca, New York, Cornell University Press.

Raniello, R. and Procaccini, G. (2002) Ancient DNA in the seagrass Posidonia oceanica. Marine Ecology - Progress Series 227, 269-273.

Roder, M.S., Korzun, V., Wendehake, K., Plaschke, J., Tixier, M.H., Leroy, P. and Ganal, M.W. (1998) A microsatellite map of wheat. Genetics 149, 2007-2023.

Saltonstall, K. (2003) Microsatellite variation within and among North American lineages of Phragmites australis. Molecular Ecology 12, 1689-1702.
Schermann, Sz. (1966) Magismeret, Vols I and II (Seed Atlas, in Hungarian). Budapest, Akadémiai Kiado.

Skøt, L., Hamilton, N.R.S., Mizen, S., Chorlton, K.H. and Thomas, I.D. (2002) Molecular genecology of temperature response in Lolium perenne: 2. Association of AFLP markers with ecogeography. Molecular Ecology 11, 1865-1876.

Smith, P.M. (1976) Minor crops. pp. 301-324 in Simmonds, N.W. (Ed.) Evolution of crop plants. London, Longman.

Sun, G., Kaushal, R., Pal, P., Wolujewicz, M., Smelser, D., Cheng, H., Lu, M., Chakraborty, R., Jin, L. and Deka, R. (2005) Whole-genome amplification: relative efficiencies of the current methods. Legal Medicine 7, 279-286.

Szabo, Z., Gyulai, G., Humphreys, M., Horváth, L., Bittsánszky, A., Lagler, R. and Heszky, L. (2005) Genetic variation of melon (C. melo) compared to an extinct landrace from the Middle Ages (Hungary) I. rDNA, SSR and SNP analysis of 47 cultivars. Euphytica 146, 87-94.

Threadgold, J. and Brown, T.A. (2003) Degradation of DNA in artificially charred wheat seeds. Journal of Archaeological Science 30, 1067-1076.

Toth, G., Gaspari, Z. and Jurka, J. (2000) Microsatellites in different eukaryotic genomes: survey and analysis. Genome Research 10, 967-981.

Vos, P., Hogers, R., Bleeker, M., Reijans, M., van de Lee, T., Hornes, M., Friters, A., Pot, J., Paleman, J., Kuiper, M. and Zabeau, M. (1995) AFLP: a new technique for DNA fingerprinting. Nucleic Acids Research 23, 4407-4414.

Walters, T.W. (1989) Historical overview on domesticated plants in China with special emphasis on the Cucurbitaceae. Economic Botany 43, 297-313.

Willerslev, E., Hansen, A.J., Binladen, J., Brand, T.B., Gilbert, M.T.P., Shapiro, B., Bunce, M., Wiuf, C., Gilichinsky, D.A. and Cooper, A. (2003) Diverse plant and animal genetic records from Holocene and Pleistocene sediments. Science 300, 791-795.

Yang, H. (1997) Ancient DNA from Pleistocene fossils: preservation, recovery, and utility of ancient genetic information for quaternary research. Quaternary Science Reviews 16, 1145-1161.

Received 17 October 2005 accepted after revision 2 June 2006 (C) CAB International 2006 